\title{
Toxicological and ultrastructural analysis of the impact of pesticides used in temperate fruit crops on two populations of Chrysoperla externa (Neuroptera, Chrysopidae)
}

\author{
Alexandre Pinho de Moura ${ }^{1}$, Geraldo Andrade Carvalho², Luciano Veiga Cosme ${ }^{3}$, Eduardo Alves ${ }^{4}$, \\ Marcos Botton ${ }^{5} \&$ Patrícia Sobral Silva ${ }^{6}$
}

${ }^{1}$ Laboratório de Entomologia, Embrapa Hortaliças, Empresa Brasileira de Pesquisa Agropecuária (Embrapa), Rodovia Brasília/Anápolis BR 060 km 09, Caixa Postal 218, 70359-970 Brasília-DF, Brasil. apmoura@cnph.embrapa.br

${ }^{2}$ Laboratório de Estudos de Seletividade, Departamento de Entomologia, Universidade Federal de Lavras (UFLA), Campus da UFLA, Caixa Postal 3037, 37200-000 Lavras-MG, Brasil. gacarval@den.ufla.br

${ }^{3}$ Laboratory of Evolutionary Genetics of Mosquitoes, Department of Entomology, College Station; Texas A \& M University, Olsen Boulevard, Texas, 77807, United States of America. 1vcosme@yahoo.com.br

${ }^{4}$ Laboratório de Microscopia Eletrônica, Departamento de Fitopatologia, Universidade Federal de Lavras (UFLA), Campus da UFLA, Caixa Postal 3037, 37200-000 Lavras-MG, Brasil. ealves@ufla.br

${ }^{5}$ Laboratório de Entomologia, Embrapa Uva e Vinho, Empresa Brasileira de Pesquisa Agropecuária (Embrapa), Rua Livramento, 515, Caixa Postal 130, 95700-000 Bento Gonçalves-RS, Brasil. marcos@cnpuv.embrapa.br

${ }^{6}$ Instituto Federal de Mato Grosso, Campus São Vicente, Rodovia BR 364 km 329, 78106-960 Santo Antônio do Leverger-MT, Brasil. patricialpp@hotmail.com

\begin{abstract}
Toxicological and ultrastructural analysis of the impact of pesticides used in temperate fruit crops on two populations of Chrysoperla externa (Neuroptera, Chrysopidae). This study aimed to evaluate the effects of ( $\mathrm{g}$ a.i. $\left.\mathrm{L}^{-1}\right)$ abamectin $(0.02)$, carbaryl (1.73), sulphur (4.8), fenitrothion (0.75), methidathion (0.4), and trichlorfon (1.5) on the survival of larvae and pupae, on the oviposition of adults and hatching of eggs from treated Chrysoperla externa third-instar larvae from two different populations (Bento Gonçalves and Vacaria, Rio Grande do Sul State, Brazil). Morphological changes caused by abamectin to eggs laid by $C$. externa from Vacaria population were evaluated by mean of ultrastructural analysis. The pesticides were applied on glass plates. Distilled water was used as control. For the evaluation of larvae mortality, a fully randomized experimental design in a $2 \times 7$ (two populations $\mathrm{x}$ seven treatments) factorial scheme was used, whereas for the effects of the compounds on oviposition capacity and egg viability, a 2 x 4 factorial scheme was used. Carbaryl, fenitrothion, and methidathion caused $100 \%$ mortality of larvae. Abamectin reduced the hatching of eggs from treated third-instar larvae of both populations; however, this pesticide presented highest toxicity on insects from Vacaria. The ultrastructural analysis showed that abamectin caused malformations in micropyle and in chorion external surface of C. externa eggs. Based in the total effect (E), carbaryl, fenitrothion, and methidathion are harmful to C. externa; trichlorfon is harmless to third-instar larvae, while abamectin and sulphur are harmless and slightly harmful to third-instar larvae from Bento Gonçalves and Vacaria, respectively.
\end{abstract}

KEYWORDS. Green lacewings; integrated pest management; natural enemy; scanning electronic microscopy; side-effects.

RESUMO. Análises toxicológica e ultra-estrutural do impacto de agrotóxicos usados no cultivo de frutíferas de clima temperado sobre duas populações de Chrysoperla externa (Neuroptera, Chrysopidae). Avaliaram-se os efeitos de (g i.a. $\left.\mathrm{L}^{-1}\right)$ abamectina $(0,02)$, carbaril $(1,73)$, enxofre $(4,8)$ fenitrotiona $(0,75)$, metidationa $(0,4)$ e triclorfom $(1,5)$ sobre a sobrevivência de larvas e pupas, na oviposição de adultos e viabilidade de ovos de Chrysoperla externa de duas populações (Bento Gonçalves e Vacaria, Rio Grande do Sul). Alterações morfológicas causadas por abamectina em ovos depositados por C. externa da população de Vacaria foram avaliadas por meio de análises ultra-estruturais. Os agrotóxicos foram aplicados sobre placas de vidro. Água destilada foi utilizada como testemunha. Para avaliação da mortalidade de larvas utilizou-se delineamento experimental inteiramente ao acaso, em esquema fatorial 2 x 7 (duas populações x sete tratamentos) e para avaliação dos efeitos dos compostos sobre a capacidade de oviposição e viabilidade de ovos utilizou-se esquema fatorial $2 \times 4$. Carbaril, fenitrotiona e metidationa causaram $100 \%$ de mortalidade das larvas. Abamectina reduziu a viabilidade de ovos de C. externa, provenientes de larvas de terceiro ínstar de ambas as populações; entretanto, apresentou toxicidade mais elevada sobre insetos de Vacaria. Análises ultra-estruturais evidenciaram que abamectina causou deformações na micrópila e na superfície externa do córion de ovos de C. externa. Baseando-se no efeito total (E), carbaril, fenitrotiona e metidationa são prejudiciais a C. externa; triclorfom é inócuo, enquanto abamectina e enxofre são inócuos e levemente prejudiciais a larvas de terceiro ínstar oriundas de Bento Gonçalves e Vacaria, respectivamente.

PALAVRAS-CHAVE. Crisopídeos; efeitos adversos; manejo integrado de pragas; microscopia eletrônica de varredura; inimigo natural.

Temperate fruit crops (apple, peach, and grape) are an important economic activity for growers located in Southern Brazil, where they are grown in ca. of 139,000 ha (Agrianual
2008). Several species of arthropod-pests are associated to temperate fruit crops mainly the oriental fruit moth Grapholita molesta (Busk, 1916), the apple leafroller Bonagota salubricola 
(Meyrick, 1937) (Lepidoptera, Tortricidae), and the South American fruit fly Anastrepha fraterculus (Wiedemann, 1830) (Diptera, Tephritidae), all of them considered key pests and limiting factors to fruit production (Botton et al. 2003; Kovaleski \& Ribeiro 2003; Arioli et al. 2004). To control these species, organophosphorous and carbamates compounds are largely used in orchards. As a consequence of the broad spectrum insecticide use, secondary outbreaks of mites are often observed in field conditions resulting in additional spraying of miticides.

One way to reduce the amount of pesticides used in orchards is to combine the use of predator insects, mainly Chrysoperla externa (Hagen, 1861) (Neuroptera, Chrysopidae) and selective pesticides. This species, besides being native to the Neotropical region (Freitas \& Penny 2001), presents desirable traits for use in programs of applied biological control (Carvalho \& Souza 2002). The green lacewings species has been reported as efficient biological control agents of the San Jose scale Quadraspidiotus perniciosus (Comstock, 1881) (Hemiptera, Diaspididae), the apple aphid Aphis citricola van der Goot, 1912 (Hemiptera, Aphididae), the citrus mealybug Planococcus citri (Risso, 1813) (Hemiptera, Pseudococcidae), and the European red spider mite Panonychus ulmi (Koch, 1836) (Acari, Tetranychidae) (Ribeiro \& Flores 2002; Bezerra et al. 2006; Giolo et al. 2009), important arthropod-pests of apple and peach orchards in Southern Brazil.

Thus, this work was carried out aiming to evaluate the sideeffects of some pesticides used in the temperate fruit production in Brazil, on third-instar larvae of C. externa (the most important chrysopid species on the Neotropical region) from two different populations of the predator (originated from Bento Gonçalves and Vacaria, Rio Grande do Sul State), on the subsequent developmental stages of this species, and on its reproduction capacity, as well as to study possible morphological modifications caused by these pesticides to eggs laid by females from treated third-instar larvae using ultrastructural analysis through scanning electronic microscope.

\section{MATERIAL AND METHODS}

The two C. externa strains used in the bioassay were collected in commercial orchards located in Bento Gonçalves $\left(29^{\circ} 09^{\prime} 00^{\prime \prime} \mathrm{S}\right.$ and $\left.51^{\circ} 31^{\prime} 00^{\prime \prime} \mathrm{W}\right)$ and Vacaria (28 $33^{\prime} 00^{\prime \prime} \mathrm{S}$ and $50^{\circ} 42^{\prime} 21^{\prime \prime} \mathrm{W}$ ), the major counties producers of temperate fruit crops in Rio Grande do Sul State, Brazil. A culture of these two populations of C. externa was established from the collected insects, under controlled conditions at $25 \pm 2{ }^{\circ} \mathrm{C}$, $\mathrm{RH}$ of $70 \pm 10 \%$, with 12 hours of photophase, as described by Carvalho \& Souza (2009).

Pesticides. Commercial formulations of the pesticides abamectin (Vertimec $18 \mathrm{CE}-0.02 \mathrm{~g}$ a.i. $\mathrm{L}^{-1}$ ), and sulphur (Kumulus $800 \mathrm{WG}-4.8 \mathrm{~g}$ a.i. $\mathrm{L}^{-1}$ ) used for mite control, fenitrothion (Sumithion $500 \mathrm{EC}-0.75 \mathrm{~g}$ a.i. $\mathrm{L}^{-1}$ ), methidathion (Supracid $400 \mathrm{EC}-0.4 \mathrm{~g}$ a.i. $\mathrm{L}^{-1}$ ), and trichlorfon (Dipterex $500 \mathrm{SC}-1.5 \mathrm{~g}$ a.i. $\mathrm{L}^{-1}$ ) used for fruit flies control, and carbaryl (Sevin $480 \mathrm{SC}-1.73 \mathrm{~g}$ a.i. $\mathrm{L}^{-1}$ ) used for the oriental fruit moth control in temperate fruit production in Brazil were used. These pesticides are widely used to control pests and diseases on temperate fruit crops in Brazil. Distilled water was used as control.

The sprayings of the pesticides aqueous solutions and of distilled water on glass plates were performed using a Potter's tower (Burkard Scientific Ltd.), regulated at $15 \mathrm{psi} \mathrm{pol}^{-2}$, ensuring the application of $1.68-1.95 \mathrm{mg} \mathrm{cm}^{-2}$, according to the methodology suggested by the International Organization for Biological Control - IOBC (Hassan 1994; Sterk et al. 1999; van de Veire et al. 2002).

Side effects of pesticides on C.externa. In this bioassay, the test unit used was composed by a glass plate $(5 \mathrm{~mm}, 11.6$ $\mathrm{x} 9.6 \mathrm{~cm}$ ). The tested pesticides were sprayed on the glass plates as described before. The glass plates were subsequently maintained at environmental conditions to dry. Afterwards, these glass plates were disposed on a table, under controlled conditions $\left(25 \pm 2^{\circ} \mathrm{C}\right.$, RH of $70 \pm 10 \%$, with 12 hours of photophase), and on each plate a piece of styrofoam was fixed using two bands. A central disc $(7.5 \mathrm{~cm}$ diameter $)$ was cut out from the styrofoam, where was inserted a PVC pipe (7.2 $\mathrm{cm}$ diameter $\mathrm{x} 2 \mathrm{~cm}$ high), thus establishing a contact area $\left(\approx 40.7 \mathrm{~cm}^{2}\right)$ of the insects to the plates containing residues of pesticides. The upper ends of each PVC pipe were closed with a fine tulle type cloth, and the inner walls of the pipes coated with polytetrafluoroethylene (fluon), to avoid the holding and the locomotion of the larvae in the PVC pipe wall, and consequently its escape, ensuring the contact of the insect with the treated surface.

Then, third-instar larvae of C. externa up to 24 hours old, obtained from the culture, were placed one by arena and fed ad libitum, every three days, with UV-killed eggs of the factitious prey Anagasta kuehniella (Zeller, 1879) (Lepidoptera, Pyralidae). Thirty third-instar larvae of C. externa were used by treatment, for each population of this predator. The larvae were maintained in the arenas until the pupae stage.

A fully randomized experimental design, in a factorial scheme 2 x 7 (two populations x seven treatments) was used. Six replicates were used by treatment, being the replicate composed by five third-instar larvae of C. externa.

Aiming to evaluate the side-effects of the pesticides on the subsequent stages of C. externa, five days after the pupae obtaining, they were transferred one by one to glass tubes (8.5 cm high $\times 2.5 \mathrm{~cm}$ diameter), which were closed with PVC film and maintained at $25 \pm 2{ }^{\circ} \mathrm{C}$, RH of $70 \pm 10 \%$, with 12 hours of photophase, until the adults emergence.

The emerged adults, up to 24 hours old, were separated by sex. A couple of $C$. externa (one male and one female) was placed by PVC cage ( $8 \mathrm{~cm}$ high $x 7.5 \mathrm{~cm}$ diameter), which had its inner wall coated with white filter paper. The PVC cages were closed at the upper end with organza type cloth, and placed on plastic tray $(40 \mathrm{~cm}$ length $\mathrm{x} 20 \mathrm{~cm}$ width $\mathrm{x} 10 \mathrm{~cm}$ height), being the adults fed with brewer's yeast and honey in the proportion of $1: 1(\mathrm{v} / \mathrm{v})$. Distilled water was available to the insects, within glass tubes with $8 \mathrm{~mL}$ capacity, containing a piece of cotton. 
Cages containing the couples of $C$. externa were placed in plastic tray, at the same controlled conditions described before. Evaluations were done twice a day, at every 12 hours intervals, until the beginning of the oviposition. During four consecutive weeks, the oviposition capacity and the hatching of eggs were evaluated. Also, the mortality of larvae and pupae, and the sex ratio of adults were studied. In order to determine the hatched eggs, at three days intervals, 96 eggs by treatment were individualized into microtitulation plate compartments used in ELISA tests (Enzyme-Linked Immunosorbent Assay). The ELISA plates were covered with PVC film and kept under controlled conditions during seven days.

For the bioassay with adults from third-instar larvae, a fully randomized experimental design, in a factorial scheme $2 \times 4$ (two populations $x$ four treatments; control, abamectin, sulphur, and trichlorfon), with six replicates and the plot being composed by a couple of $C$. externa was used. Only four pesticides were tested in the bioassay with adults, because the compounds carbaryl, fenitrothion, and methidathion caused $100 \%$ mortality rates to treated third-instar larvae of C. externa. In order to assess the hatching of eggs laid by females from treated third-instar larvae, eight replicates were used, each one being composed by 12 eggs.

Pesticides classification. Mortality rates of insects, from the tested stage until the adult phase were corrected by Abbott's formula, according to the control (Abbott 1925). Then, the pesticides were classified into toxicological categories based on the reduction of the oviposition capacity and the hatching of eggs, and mortality caused to the predator, using the Equation 1, proposed by Vogt (1992):

$\mathrm{E}=100 \%-(100 \%-\mathrm{M} \%) \times \mathrm{R}_{1} \times \mathrm{R}_{2}{ }^{(1)}$ with: $\mathrm{E}=$ total effect $(\%) ; \mathrm{M} \%=$ corrected mortality in function of the control (Abbott 1925); $\mathrm{R}_{1}=$ ratio of daily mean amount of laid eggs between females from treated and untreated third-instar larvae; $R_{2}=$ ratio between the hatched eggs mean laid by females from treated and untreated third-instar larvae.

The evaluated pesticides were classified into toxicological categories, according to recommendations of the IOBC (Hassan 1994; Sterk et al. 1999; van de Veire et al. 2002), in 4 classes: class $1=$ harmless $(\mathrm{E}<30 \%)$, class $2=$ slightly harmful $(30 \% \leqslant \mathrm{E} \leqslant 80 \%)$, class $3=$ moderately harmful $(80 \%<\mathrm{E} \leqslant 99 \%)$, and class $4=$ harmful $(\mathrm{E}>99 \%)$.

Statistical analysis. The obtained data (mortality rates, sex ratio, oviposition capacity, and hatching of eggs) in the bioassays were submitted to analysis of variance (ANOVA), using a two-way ANOVA, and the data referring to the number of eggs (oviposition capacity) laid by female of C. externa and to the hatching of eggs followed a split spot arrangement. Means of the different treatments were compared using the Scott-Knott clustering test (Scott \& Knott 1974), at $5 \%$ significance, when the $F$-test was significant, using the statistical software SAS (SAS Institute 2001). The mortality data obtained from the bioassay with third-instar larvae were angular-transformed (arcsine $\sqrt{ } \mathrm{x} / 100$ transformation), before processing variance analysis.

Ultrastructural analysis of $\boldsymbol{C}$. externa eggs. Eggs laid by females from Vacaria population, originated from abamectin-treated and distilled water-treated third-instar larvae were prepared for later studies under scanning electronic microscope, as abamectin reduced hatching of eggs rates through evaluations.

Twenty newly laid eggs were used per treatment and were transferred to micro centrifuge tubes (Eppendorf) with capacity to $2.0 \mathrm{~mL}$, and subjected to a protocol for biological sampling preparation, according to the laboratory's routine techniques (Alves et al. 2008). Afterwards, the samples were studied under a scanning electronic microscope (LEO Evo40 XVP; Leo Electron Microscopy).

\section{RESULTS}

Among the tested pesticides, carbaryl, fenitrothion, and methidathion caused $100 \%$ mortality of $C$. externa larvae from both studied populations (Table I). Sulphur and abamectin were innocuous to third-instar larvae, with mortality rates ranging from zero to $10 \%$. Trichlorfon just caused significant mortality of larvae from Bento Gonçalves, being innocuous to those from Vacaria. For pupae from treated larvae, trichlorfon, sulphur, and abamectin presented cumulative mortality rates similar to the control. Sex ratio of obtained adults was not affected by the pesticides.

Table I. Cumulative mortality (\%) and sex ratio $( \pm \mathrm{SEM})^{(1)}$ of Chrysoperla externa from Bento Gonçalves (BG) and from Vacaria (VAC) counties, Rio Grande do Sul State, Brazil, originated from treated third-instar larvae ${ }^{(2)}$.

\begin{tabular}{|c|c|c|c|c|c|c|}
\hline \multirow{2}{*}{ Treatment } & \multicolumn{2}{|c|}{ Third-instar } & \multicolumn{2}{|c|}{ Pupae } & \multicolumn{2}{|c|}{ Sex ratio ${ }^{(\mathrm{ns})}$} \\
\hline & BG & VAC & $\mathrm{BG}$ & VAC & BG & VAC \\
\hline Control & $3.3 \pm 1.67 \mathrm{C}$ & $0.0 \pm 0.00 \mathrm{~B}$ & $6.7 \pm 4.22 \mathrm{~B}$ & $0.0 \pm 0.00 \mathrm{~B}$ & $0.6 \pm 0.11$ & $0.7 \pm 0.10$ \\
\hline Trichlorfon & $23.3 \pm 9.55 \mathrm{~B}$ & $13.3 \pm 4.22 \mathrm{~B}$ & $23.3 \pm 9.55 \mathrm{~B}$ & $13.3 \pm 4.22 \mathrm{~B}$ & $0.6 \pm 0.09$ & $0.4 \pm 0.08$ \\
\hline Sulphur & $0.0 \pm 0.00 \mathrm{C}$ & $10.0 \pm 4.47 \mathrm{~B}$ & $6.7 \pm 4.22 \mathrm{~B}$ & $10.0 \pm 4.47 \mathrm{~B}$ & $0.4 \pm 0.12$ & $0.4 \pm 0.12$ \\
\hline Carbaryl & $100.0 \pm 0.00 \mathrm{~A}$ & $100.0 \pm 0.00 \mathrm{~A}$ & $100.0 \pm 0.00 \mathrm{~A}$ & $100.0 \pm 0.00 \mathrm{~A}$ & - & - \\
\hline Fenitrothion & $100.0 \pm 0.00 \mathrm{~A}$ & $100.0 \pm 0.00 \mathrm{~A}$ & $100.0 \pm 0.00 \mathrm{~A}$ & $100.0 \pm 0.00 \mathrm{~A}$ & - & - \\
\hline Methidathion & $100.0 \pm 0.00 \mathrm{~A}$ & $100.0 \pm 0.00 \mathrm{~A}$ & $100.0 \pm 0.00 \mathrm{~A}$ & $100.0 \pm 0.00 \mathrm{~A}$ & - & - \\
\hline Abamectin & $3.3 \pm 1.67 \mathrm{C}$ & $10.0 \pm 6.83 \mathrm{~B}$ & $16.7 \pm 6.15 \mathrm{~B}$ & $10.0 \pm 6.83 \mathrm{~B}$ & $0.5 \pm 0.13$ & $0.4 \pm 0.11$ \\
\hline
\end{tabular}

(1) Standard error of the mean; ${ }^{(2)}$ Means followed by the same capital letter in columns are no different by the Scott-Knott test (P $\left.>0.05\right)$; ${ }^{\text {(n) }}$ Non-significant by the $F$-test $(\mathrm{P}>0.05)$; $(-)$ Non-evaluated trait due to the high mortality caused by the pesticide. 
Trichlorfon, sulphur, and abamectin did not affect the oviposition capacity of $C$. externa originated from treated thirdinstar larvae, except in the last evaluation, for females from Vacaria. At this evaluation, sulphur and abamectin allowed oviposition rates of 22.2 and 0.5 eggs, respectively (Table II).

Trichlorfon did not decrease the hatching of eggs, which allowed viability rates varying from $90.6 \%$ to $95.9 \%$, for eggs laid by C. externa from Bento Gonçalves, and from $90.6 \%$ to $96.9 \%$, for eggs from Vacaria (Table III). Sulphur caused decreasing in the hatching of eggs laid by females from Vacaria, but just during the first and second evaluations. Abamectin affected negatively this biological trait for females from both studied populations. However, it was more harmful to insects from Vacaria, reducing the hatching of eggs during the entire period, when compared to the control. For females from Bento Gonçalves, abamectin just affected this trait during the first four assessments, providing rates varying from $60.4 \%$ to $74 \%$, during this period.

Trichlorfon was harmless (class 1), whereas carbaryl, fenitrothion, and methidathion were harmful (class 4) to both studied populations (Table IV). On the other hand, sulphur and abamectin were classified as harmless to insects from Bento Gonçalves and slightly harmful to those from Vacaria.

Ultrastructural analysis of eggs laid by $C$. externa from Vacaria, originated from abamectin-treated third-instar larvae, revealed that this pesticide changed both the chorion and the micropyle morphology, when compared to eggs from untreated females (control) (Figs. 1-3). The malformations occurrence frequencies in the abamectin samples observed under a scanning electronic microscope were about $40 \%$, for eggs laid by females from abamectin-treated third-instar larvae.

\section{DISCUSSION}

The mortality rates caused by fenitrothion and methidathion are similar to those reported by Silva et al. (2005) for chlorpyrifos (organophosphates pesticides), demonstrating the high toxicity of some of these pesticides to this beneficial insect. These authors also verified that sulphur did not caused
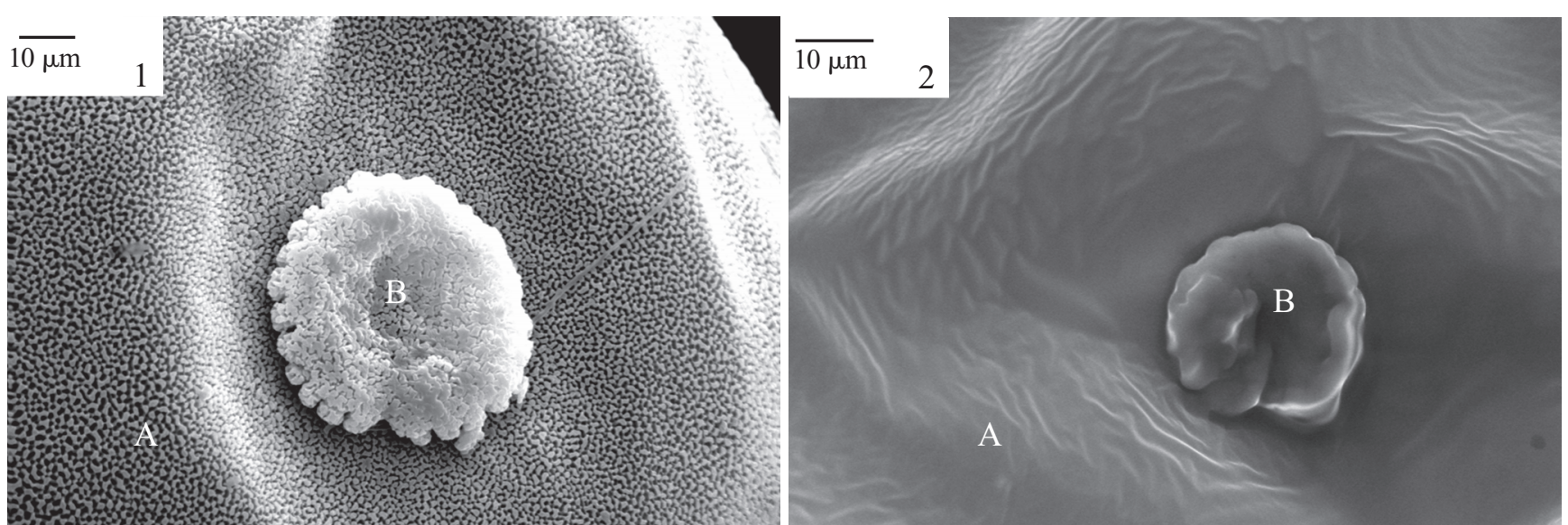

Figs. 1-2. Scanning electron micrographs showing external morphology of the chorion (A) and micropyle (B), of Chrysoperla externa eggs laid by females from Vacaria county, Rio Grande do Sul State, Brazil, originated from distilled water (1) or abamectin-treated (2) third-instar larvae (occurrence frequencies in the samples of about $40 \%$ ).
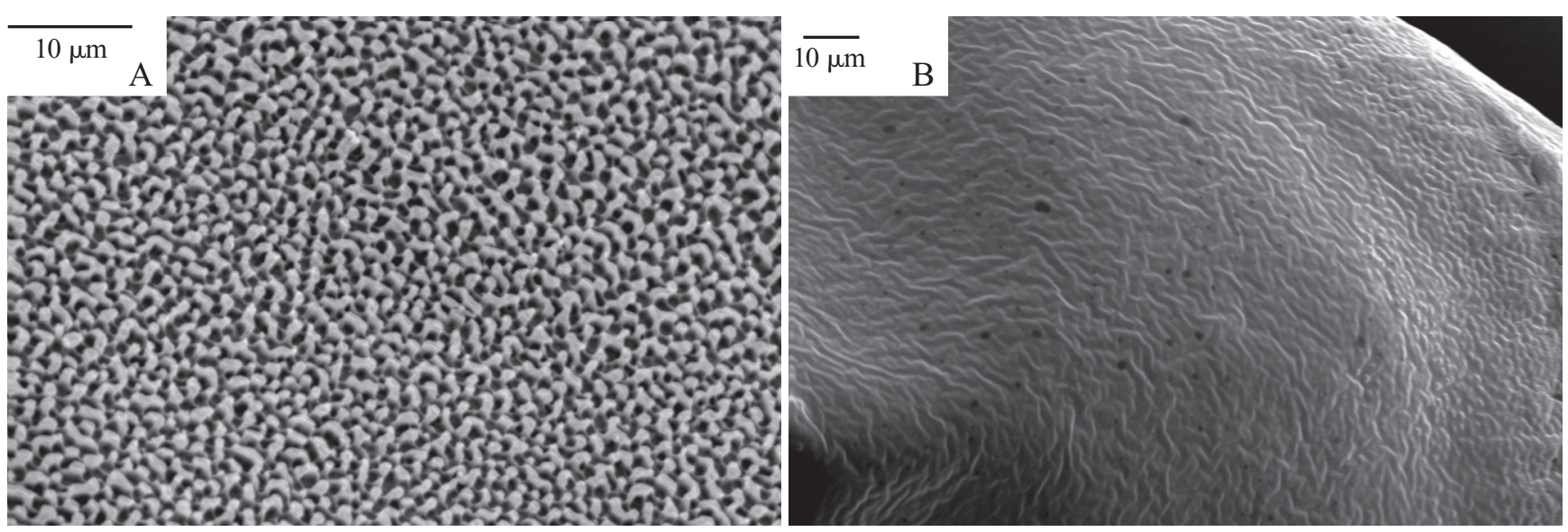

Fig. 3. Scanning electron micrographs showing external surface of the chorion of Chrysoperla externa eggs laid by females from Vacaria County, Rio Grande do Sul State, Brazil, originated from distilled water (A) or abamectin-treated (B) third-instar larvae. 

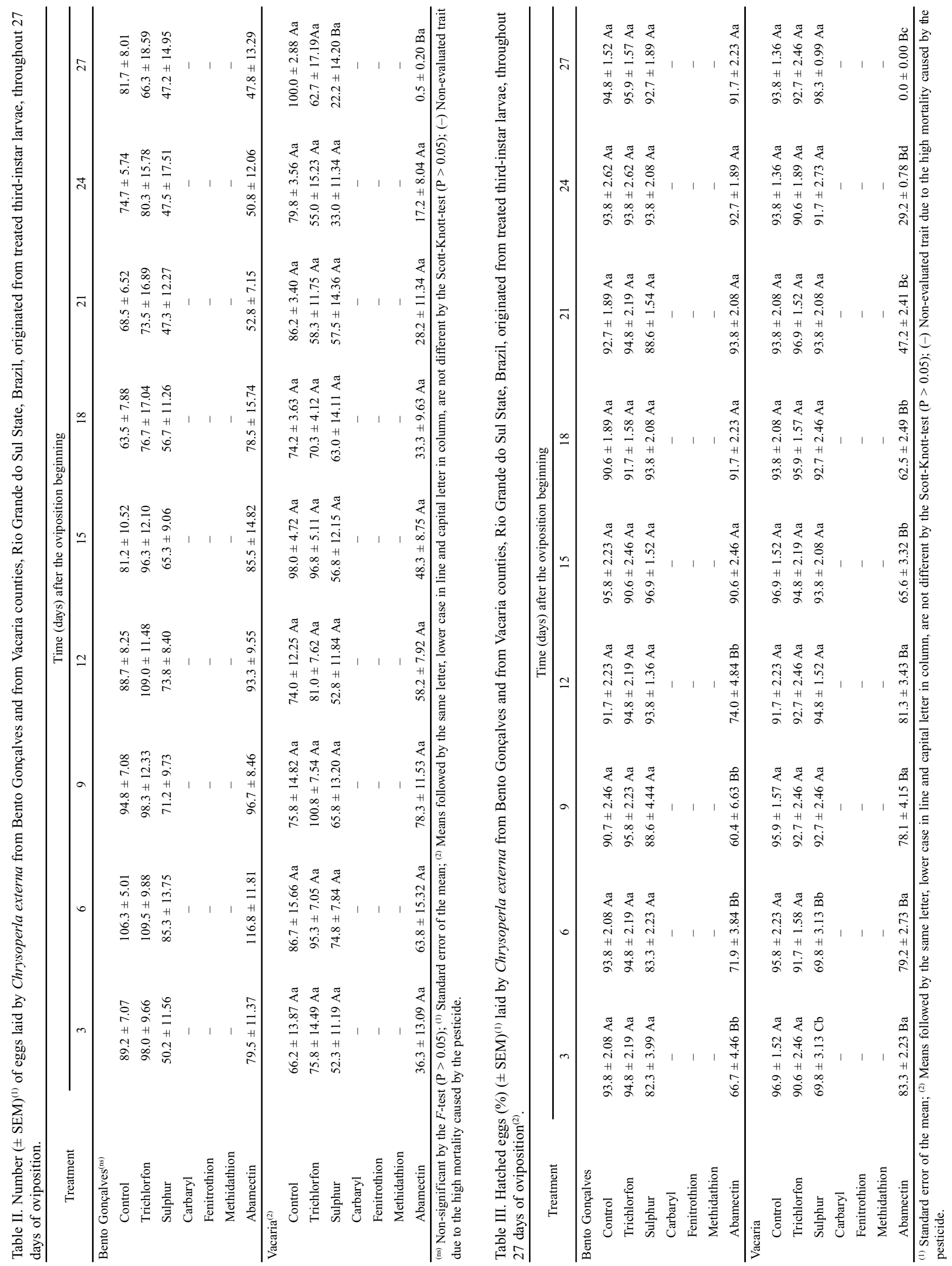
Table IV. Effects of six pesticides on the mortality (\%) of Chrysoperla externa from Bento Gonçalves and from Vacaria counties, Rio Grande do Sul State, Brazil, oviposition capacity and hatched eggs (\%), total effect (E) (\%), and toxicological classification according to the IOBC, originated from treated third-instar larvae.

\begin{tabular}{lrrrrrr}
\hline \multicolumn{1}{c}{ Treatment } & $\begin{array}{c}\text { Mortality } \\
(\%)\end{array}$ & $\begin{array}{c}\mathrm{M}^{(1)} \\
(\%)\end{array}$ & $\begin{array}{c}\mathrm{R}^{\prime(2)} \\
(\%)\end{array}$ & $\begin{array}{c}\mathrm{R}^{\prime(3)} \\
(\%)\end{array}$ & $\begin{array}{c}\mathrm{E} \\
(\%)\end{array}$ & Class $^{(4)}$ \\
\hline Bento Gonçalves & & & & & & \\
Control & 6.7 & - & 27.7 & 93.1 & - & - \\
Trichlorfon & 23.3 & 17.8 & 29.9 & 94.1 & 10.3 & 1 \\
Sulphur & 6.7 & 0.0 & 20.2 & 90.4 & 29.2 & 1 \\
Carbaryl & 100.0 & 100.0 & - & - & 100.0 & 4 \\
Fenitrothion & 100.0 & 100.0 & - & - & 100.0 & 4 \\
Methidathion & 100.0 & 100.0 & - & - & 100.0 & 4 \\
Abamectin & 16.7 & 10.7 & 26.0 & 81.5 & 26.6 & 1 \\
\hline Vacaria & & & & & & \\
Control & 0.0 & - & 27.4 & 94.7 & - & - \\
Trichlorfon & 13.3 & 13.3 & 25.8 & 93.2 & 19.7 & 1 \\
Sulphur & 10.0 & 10.0 & 17.7 & 88.6 & 45.6 & 2 \\
Carbaryl & 100.0 & 100.0 & - & - & 100.0 & 4 \\
Fenitrothion & 100.0 & 100.0 & - & - & 100.0 & 4 \\
Methidathion & 100.0 & 100.0 & - & - & 100.0 & 4 \\
Abamectin & 10.0 & 10.0 & 13.5 & 58.5 & 72.6 & 2 \\
\hline
\end{tabular}

(1) Mortality (\%) of C. externa corrected based in the control (Abbott 1925); (2) Number of eggs/female/day; ${ }^{(3)}$ Hatched eggs collected during a four weeks period; ${ }^{(4)}$ Class of toxicity proposed by the IOBC (Hassan 1994, Sterk et al. 1999, van de Veire et al. 2002), with: $1=$ harmless $(\mathrm{E}<30 \%)$; $2=$ slightly harmful $(30 \% \leqslant \mathrm{E} \leqslant 80 \%)$, and $4=$ harmful $(\mathrm{E}>99 \%)$.

significant mortality of larvae, as well as of pupae originated from treated larvae, what was observed in this study as well. It is believed that the safety of the sulphur concentration used in this study against $C$. externa is related to the highest innate tolerance of this green lacewing species to both acaricides and fungicides containing this compound in its formulation, since according to Croft (1990) these compounds are generally considered harmless to natural enemies. Also, the lack of effect of sulphur on C. externa could be related to the fact that the compound did not show capacity to act on none site of action of the insect nervous system or even preventing the energy production (ATP), because it is a fungicide, as also related by Moura et al. (2009).

For abamectin, similar results were also reported by Bueno $\&$ Freitas (2004), who verified mortality rates of $6.7 \%$ of the late pupae. Studies developed by Giolo et al. (2009) evidenced that abamectin caused cumulative mortality of $22.9 \%$ (percentage of dead larvae and pupae) to Chrysoperla carnea (Stephens, 1836), when first-instar larvae were exposed to fresh dry residues of this pesticide until pupation. The highest mortality reported by Giolo et al. (2009) for abamectin is related to the use of first-instar larvae, which are more sensible when compared to third-instar larvae.

However, the results obtained to trichlorfon differ from those reported by Carvalho et al. (2002), who found mortality rates of $98 \%$ of treated third-instar larvae of C. externa, six hours after the pesticide application. Probably, the differences between the results found in this study and those found by Carvalho et al. (2002) are related to the methodology employed by these authors, who applied the pesticide directly on larvae. Nevertheless, trichlorfon was innocuous to first-instar larvae of $C$. carnea causing cumulative mortality rate of $5.7 \%$ (percentage of dead larvae and pupae) (Giolo et al. 2009).

Probably, the low toxicity presented by trichlorfon is related to the high tolerance of insects belonging to the Family Chrysopidae to this pesticide, as reported by Croft (1990). This author verified that $C$. carnea show high tolerance to trichlorfon, due to the lower penetration capacity of the pesticide through the insect integument, what likely also occurred in the present study.

The differentiated tolerance of the evaluated C. externa populations found in this study may be associated to their different geographical origins, as also reported by Bleicher \& Parra (1990), by Brunner et al. (2001), and by Moura et al. (2005) for arthropod-pests parasitoids, as well as to different expositions of the populations to specific pesticides, occurring in their original habitat (history of use of pesticides), what according to Croft (1990), may lead to selection of tolerant individuals, and differentiate their response to pesticides under laboratory conditions. In fact, insects originated from Vacaria orchards had history of exposure to the evaluated pesticides, as these pesticides are used to control pests and diseases in temperate fruit crops, what may result in a higher tolerance of insects from Vacaria to these compounds when compared to insects from Bento Gonçalves.

Regarding to the sex ratio of C. externa, was not found in the scientific literature, an explanation about the side-effects of the pesticides on this biological parameter. Nevertheless, Silva et al. (2005) also not reported negative effects of sulphur on the sex ratio of this green lacewing species.

Oviposition rates obtained for abamectin, as well as to sulphur, confirmed those found by Godoy et al. (2004) and by Giolo et al. (2009) for abamectin, and by Silva et al. (2005) for sulphur, who also not found decreasing in this biological trait of green lacewings, demonstrating that they are selective to the predator.

Decreases in hatching of eggs, as observed to eggs from C. externa originated from abamectin-treated third-instar larvae, can be the outcome of side-effects of this pesticide on oogenesis of this species, possibly on trophocytes, sisters-cells of the oocytes, which are responsible for their nutrition. It can be also due to the accumulation, within the oocytes, of proteins contaminated with the pesticide, from the insect hemolymph. According to Chapman (1998), the trophocytes malformation or even the absorption of contaminated proteins by these cells, may result in the lack of nutrients for the embryos or cause changes in its development, leading them to death. This way, this pesticide must have affected such physiological events and caused a reduction in hatching rates of those eggs.

The toxicological classification assigned to abamectin, for insects from Bento Gonçalves is similar to that gave to this pesticide by Godoy et al. (2004) to C. externa, who re- 
ported total effect (E) of 7.7\%. Bueno \& Freitas (2004) and Giolo et al. (2009) also classified abamectin as harmless to green lacewings.

Similar classification found to sulphur in this study, to insects from Vacaria, was also reported by Silva et al. (2005) on C. externa. These authors verified total effect (E) of $26.3 \%$ to this pesticide against third-instar larvae.

In this study, fenitrothion and methidathion were harmful to $C$. externa, receiving the same classification reported by Silva et al. (2005) to chlorpyrifos, belonging to the organophosphates chemical group, causing $100 \%$ mortality of insects. On the other hand, Giolo et al. (2009) classified trichlorfon as harmless to $C$. carnea, corroborating the results found in our study.

Differences in the classification assigned to abamectin and sulphur, between the tested $C$. externa populations in this study are due to the effects of these pesticides on the oviposition capacity and on the hatching of eggs obtained to this species. Similar effects were also reported by Rezaei et al. (2007), who studied the side-effects of imidacloprid, propargite, and pymetrozine on C. carnea larvae.

Changes in the external chorion surface of eggs laid by females from abamectin-treated third-instar larvae suggests that they might have been induced by changes in the folicular cells, responsible for the secretion of chorion layers, since according to Chapman (1998), shape modifications caused to the above mentioned cells are reflected in the chorion morphology. However, changes in the cells constitution may also be responsible for modification in the chorion surface, since the proteins synthesized by folicular cells behave as basic material to the chorion formation. These proteins also may affect the formation of aeropyle, micropyle and other chorion pores.

It is believed that the abnormalities caused by abamectin to both chorion and micropyle of eggs laid by C. externa from treated third-instar larvae, may be responsible for the decreasing in the hatching of egg. Although no ultrastructural analysis have been carried out on eggs laid by females from Bento Gonçales, it is believed that decreases in the hatching of eggs during the first four evaluations may also be due to the morphological malformations in both the chorion surface and in the micropyle, as reported to insetcs from Vacaria.

According to Mazzini (1976) and Chapman (1998), alterations in any of the chorion layers may affect its permeability, and consequently, the loss of water, the embryonic development, and the hatching of egg. Still according to the same authors, abnormalities in the cellular processes which are responsible for the micropyle formation may inhibit access for the sperm to the inner side of the egg, interfering in its fertilization and therefore in its viability.

In conclusion, carbaryl, fenitrothion, and methidathion are harmful to third-instar larvae of both Bento Gonçalves and Vacaria $C$. externa populations, and should be avoided in the control of pests in temperate fruit crops, in association with this predator. Sulphur and abamectin are harmless and slightly harmful to C. externa from Bento Gonçalves and Vacaria, respectively, whereas trichlorfon is harmless to both studied populations. Abamectin causes abnormalities in both chorion surface and micropyle of eggs laid by C. externa from Vacaria. Therefore, sulphur and trichlorfon could have their use encouraged in the temperate fruit pests control, while abamectin should be avoided. We hope that these findings can be useful for temperate fruit growers to minimize the side-effects of pesticides frequently used to control pests and diseases, on arthropod biological control agents and to decrease the risks to the growers, to the consumers and the impact to the environment.

\section{ACKNOWLEDGEMENTS}

The authors thank the "Conselho Nacional de Desenvolvimento Científico e Tecnológico (CNPq)" and the "Fundação de Amparo à Pesquisa do Estado de Minas Gerais (FAPEMIG)" for scholarships provided; to MSc. Eloísa Leite, from the "Departamento de Fitopatologia, Universidade Federal de Lavras", Brazil, for her great help with ultrastructural analysis; to Dr. András Bozsik, from the Department of Plant Protection, Faculty of Agricultural Sciences, Debrecen University, Hungary, and to Dr. Massimo Mazzini, Department of Environmental Sciences, Tuscia University, Italy, for sending bibliographical material that helped in the results discussion.

\section{REFERENCES}

Abbott, W. S. 1925. A method of computing the effectiveness of an insecticide. Journal of Economic Entomology 18: 265-267.

Agrianual. 2008. Anuário da agricultura brasileira. São Paulo, Instituto FNP, 502 p.

Alves, E.; B. Leite; R. C. Marucci; S. F. Pascholati; J. R. S. Lopes \& P. C. Andersen. 2008. Retention sites for Xylella fastidiosa in four sharpshooter vectors (Hemiptera: Cicadellidae) analyzed by scanning electron microscopy. Current Microbiology 56: 531-538.

Arioli, C. J.; M. Botton \& G. A. Carvalho. 2004. Controle químico da Grapholita molesta (Busck) (Lepidoptera: Tortricidae) na cultura do pessegueiro. Ciência Rural 34: 1695-1700.

Bezerra, G. C. D.; L. V. C. Santa-Cecília; C. F. Carvalho \& B. Souza. 2006. Aspectos biológicos da fase adulta de Chrysoperla externa (Hagen, 1861) (Neuroptera: Chrysopidae) oriunda de larvas alimentadas com Planococcus citri (Risso, 1813) (Hemiptera: Pseudococcidae). Ciência e Agrotecnologia 30: 603-610.

Bleicher, E. \& J. R. P. Parra. 1990. Espécies de Trichogramma parasitóides de Alabama argillacea III. Determinação das exigências térmicas de três populações. Pesquisa Agropecuária Brasileira 25: 215-219.

Botton, M.; E. R. Hickel \& S. J. Soria. 2003. Pragas, p. 82-107. In: T. V. M. Fajardo (ed.). Uvas para Processamento: Fitossanidade. Brasília, Embrapa Informação Tecnológica, 131 p.

Bueno, A. F. \& S. Freitas. 2004. Effect of the insecticides abamectin and lufenuron on eggs and larvae of Chrysoperla externa under laboratory conditions. BioControl 49: 277-283.

Brunner, J. F.; J. E. Dunley; M. D. Doerr \& E. H. Beers. 2001. Effect of pesticides on Colpoclypeus florus (Hymenoptera: Eulophidae) and Trichogramma platneri (Hymenoptera: Trichogrammatidae), parasitoids of leafrollers in Washington. Journal of Economic Entomology 94: 1075-1084.

Carvalho, C. F. \& B. Souza. 2002. Potencial de insetos predadores no controle biológico aplicado, p. 191-208. In: J. R. P. Parra; P. S. M. Botelho; B. S. Corrêa-Ferreira \& J. M. S. Bento (ed.). Controle Biológico no Brasil: Parasitóides e Predadores. São Paulo, Manole, xxvi+609 p. 
Carvalho, C. F. \& B. Souza. 2009. Métodos de criação e produção de crisopídeos, p. 77-115. In: V. H. P. Bueno (ed.). Controle Biológico de Pragas: Produção Massal e Controle de Qualidade. Lavras, UFLA, $430 \mathrm{p}$

Carvalho, G. A.; C. F. Carvalho; B. Souza \& J. L. R. Ulhôa. 2002. Seletividade de inseticidas a Chrysoperla externa (Hagen) (Neuroptera: Chrysopidae). Neotropical Entomology 31: 615-621.

Chapman, R. F. 1998. The Insects: Structure and Function. Cambridge, Cambridge University Press, xvii+770 p.

Croft, B. A. 1990. Arthropod Biological Control Agents and Pesticides. New York, Wiley-Interscience, xii+723 p.

Freitas, S. \& N. D. Penny. 2001. The green lacewings (Neuroptera: Chrysopidae) of Brazilian agro-ecosystems. Proceedings of the California Academy of Sciences 52: 245-395.

Giolo, F. P.; P. Medina; A. D. Grützmacher \& E. Viñuela. 2009. Effects of pesticides commonly used in peach orchards in Brazil on predatory lacewing Chrysoperla carnea under laboratory conditions. BioControl 54: $625-635$.

Godoy, M. S.; G. A. Carvalho; J. C. Moraes; M. M. Goussain; A. A. Morais \& L. V. Cosme. 2004. Seletividade de inseticidas utilizados na cultura dos citros para ovos e larvas de Chrysoperla externa (Hagen) (Neuroptera: Chrysopidae). Neotropical Entomology 33: 639-646.

Hassan, S. A. 1994. Activities of the IOBC/WPRS working group "Pesticides and Beneficial Organisms". IOBC/WPRS Bulletin 17: 1-5.

Kovaleski, A. \& L. G. Ribeiro. 2003. Manejo de Pragas na Produção Integrada de Maçã, p. 61-68. In: J. F. S. Protas \& R. M. V. Sanhueza (ed.). Produção Integrada de Frutas: O Caso da Maçã no Brasil. Bento Gonçalves, Embrapa Uva e Vinho, 192 p.

Mazzini, M. 1976. Fine structure of the insect micropyle-III. Ultrastructure of the egg of Chrysopa carnea Steph. (Neuroptera: Chrysopidae). International Journal of Insect Morphology and Embryology 5: 273-278.

Moura, A. P.; G. A. Carvalho; O. Lasmar; V. F. Moscardini \& D. T. Rezende. 2009. Efeitos da aplicação de agrotóxicos utilizados na produção integrada de maçã sobre pupas de Chrysoperla externa. Ciência Rural 39: $2285-2292$
Moura, A. P.; G. A. Carvalho \& R. L. O. Rigitano. 2005. Toxicidade de inseticidas utilizados na cultura do tomateiro a Trichogramma pretiosum. Pesquisa Agropecuária Brasileira 40: 203-210.

Rezaei, M.; K. Talebi; V. H. Naveh \& A. Kavousi. 2007. Impacts of the pesticides imidacloprid, propargite and pymetrozine on Chrysoperla carnea (Stephens) (Neuroptera: Chrysopidae): IOBC and life table assays. BioControl 52: 385-398.

Ribeiro, L. G. \& E. H. Flores. 2002. Pulgão-verde: Aphis citricola Van der Goot (Homoptera: Aphididae), p. 519-521. In: EPAGRI GMC (ed.). A cultura da Macieira. Florianópolis, EPAGRI, 743 p.

SAS Institute. 2001. SAS User's Guide: Statistics. Cary, NC: SAS Institute, USA, xvi+956 p.

Scott, A. J. \& M. A. Knott. 1974. A cluster analysis method for grouping means in the analysis of variance. Biometrics 30: 507-512.

Silva, R. A.; G. A. Carvalho; C. F. Carvalho; P. R. Reis; A. M. A. R. Pereira \& L. V. Cosme. 2005. Toxicidade de produtos fitossanitários utilizados na cultura do cafeeiro a larvas de Chrysoperla externa (Hagen) (Neuroptera: Chrysopidae) e efeitos sobre as fases subseqüentes do predador. Neotropical Entomology 34: 951-959.

Sterk, G.; S. A. Hassan; M. Baillod; F. Bakker; F. Bigler; S. Blümel; H. Bogenschütz; E. Boller; B. Bromand; J. Brun; J. N. M. Callis; J. Coremans-Pelseneer; C. Duso; A. Garrido; A. Grove; U. Heimbach; H. Hokkanen; J. Jacas; G. Lewis; L. Moreth: L. Polgar; L. Roversti; L. Samsøe-Petersen; B. Sauphanor; L. Schaub; A. Stäubli; J. J. Tuset; A. Vainio; M. van de Veire; G. Viggiani; E. Viñuela \& H. Vogt. 1999. Results of the seventh joint pesticide testing programme carried out by the IOBC/WPRS-Working Group 'Pesticides and Beneficial Organisms'. BioControl 44: 99-117.

van de Veire, M; G. Sterk; M. van der Staaij; P. M. J. Ramakers \& L. Tirry. 2002. Sequential testing scheme for the assessment of the side-effects of plant protection products on the predatory bug Orius laevigatus. BioControl 47: 101-113.

Vogt, H. 1992. Untersuchugen zu Nebenwirkungen von Insektiziden und Acariziden auf Chrysoperla carnea (Stephens) (Neuroptera: Chrysopidae). Mededelingen van de Faculteit Landbouwwetenschappen Rijksuniversiteit te Gent 57: 559-567.

Received 24/3/2010; accepted 27/7/2011

Editor: Paulo Roberto Valle da Silva Pereira 